\title{
PHYSIOLOGICAL AND PHARMACOLOGICAL REGULATION OF HUMAN SALIVARY ELECTROLYTE CONCENTRATIONS; WITH A DISCUSSION OF ELECTROLYTE CONCEN- TRATIONS OF SOME OTHER EXOCRINE SECRETIONS ${ }^{1}$
}

\author{
By ABRAHAM G. WHITE,2 PAUL S. ENTMACHER, GEORGE RUBIN, AND \\ LOUIS LEITER
}

\author{
(From the Medical Division, Montefiore Hospital, New York City and the Department of \\ Medicine, The Mount Sinai Hospital, New York City, N. Y.)
}

(Submitted for publication May 18, 1954 ; accepted October 20, 1954)

The electrolyte content of paraffin-stimulated, whole, mixed saliva obtained from patients with congestive heart failure is characterized by lower sodium, lower chloride, and higher potassium concentrations than saliva of normal subjects (1). Since these data suggested possible increased adrenal cortical activity in patients with heart failure, desoxycorticosterone acetate (DCA) was administered to nineteen normal subjects. It also seemed of interest to study additional pharmacological and physiological mechanisms that may play a role in the regulation of salivary electrolyte concentrations. Thus, the aims of this communication are to present: 1) Data on normal salivary concentrations of sodium, chloride, and potassium ; 2) data relating to physiological mechanisms regulating the concentrations of salivary electrolytes; and 3 ) the effects on salivary electrolytes of three pharmacologic agents: desoxycorticosterone acetate (DCA), pilocarpine, and Mercuhydrin ${ }^{\circ}$

\section{METHODS}

Approximately $30 \mathrm{ml}$. of saliva were collected in the morning from fasting subjects who chewed paraffin for 15 to 20 minutes following a preliminary mouth wash with water. Where indicated, normal subjects chewed paraffin for two consecutive ten-minute periods. Whole, mixed saliva was analyzed. Sodium and potassium concentrations were measured with an internal standard Perkin 52A flame photometer; chloride concentrations, by the Van Slyke-Hiller iodometric method (2). Stand-

1 Aided by a grant from the American Heart Association and by a United States Public Health Service grant (H-1245).

2 This work was begun during the tenure of a Research Fellowship of the American Heart Association in 1950. Present address: The Mount Sinai Hospital, New York City. ard methods of statistical analysis were employed (3); the " $t$ " test was used to determine the statistical significance of mean differences between groups, and the method of "paired differences" was employed in evaluating the effects of pharmacologic agents on the electrolyte concentrations of saliva.

Ten mgm. DCA in oil were injected intramuscularly, daily, for 5 to 15 days into normal subjects who received a regular diet and $10 \mathrm{gm}$. supplemental salt by mouth per day. Duplicate collections of saliva were collected on consecutive days both before and during the administration of DCA in order to test the reproducibility of the values for salivary electrolyte concentrations. The concentration of potassium was not measured in one of these subjects.

Twenty-nine pairs of observations were made on the effect of $6 \mathrm{mgm}$. of subcutaneously-administered pilocarpine on the salivary electrolyte concentrations in subjects without cardiac disease. Thirty minutes after the injection of pilocarpine the subject began to chew paraffin again, and $30 \mathrm{ml}$. of saliva were collected (usually in about 10 minutes).

Two ml. of Mercuhydrin were injected intramuscularly into 10 patients with congestive heart failure and on a low salt diet. Collections of saliva were made at the time of administration, and at 11/2, 3, and 24 hours, respectively, after the injection of the mercurial diuretic.

Fifteen experiments on nine normal subjects on a regular salt diet were performed in which saliva was collected in two successive 10-minute periods in order to compare the salivary electrolyte concentrations during varying rates of flow.

\section{RESULTS}

\section{Normal concentrations of salivary electrolytes}

For the 73 control subjects on a regular salt diet, including the 16 values obtained from our earlier studies (1), the normal salivary concentrations of sodium, chloride, and potassium are $26.4 \pm 11.8,29.0 \pm 8.8$, and $19.7 \pm 3.9 \mathrm{mEq}$. per L., respectively. 


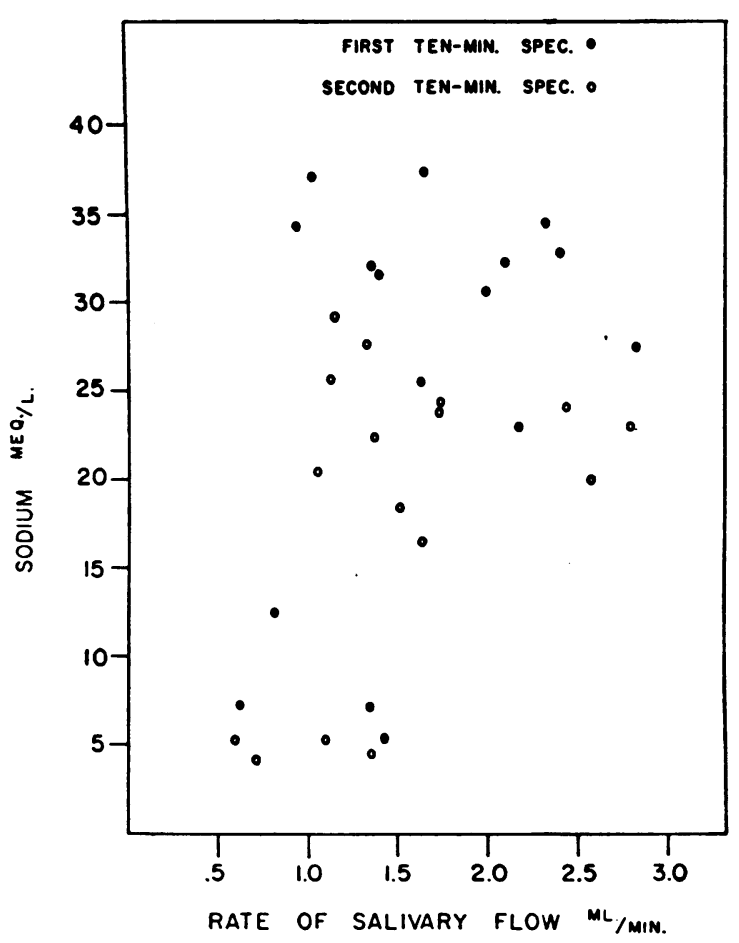

Fig. 1. Relation of the Salivary Concentration of Sodium (mEQ. per L.) to Rate of Salivary Flow (ML. PER MIN.)

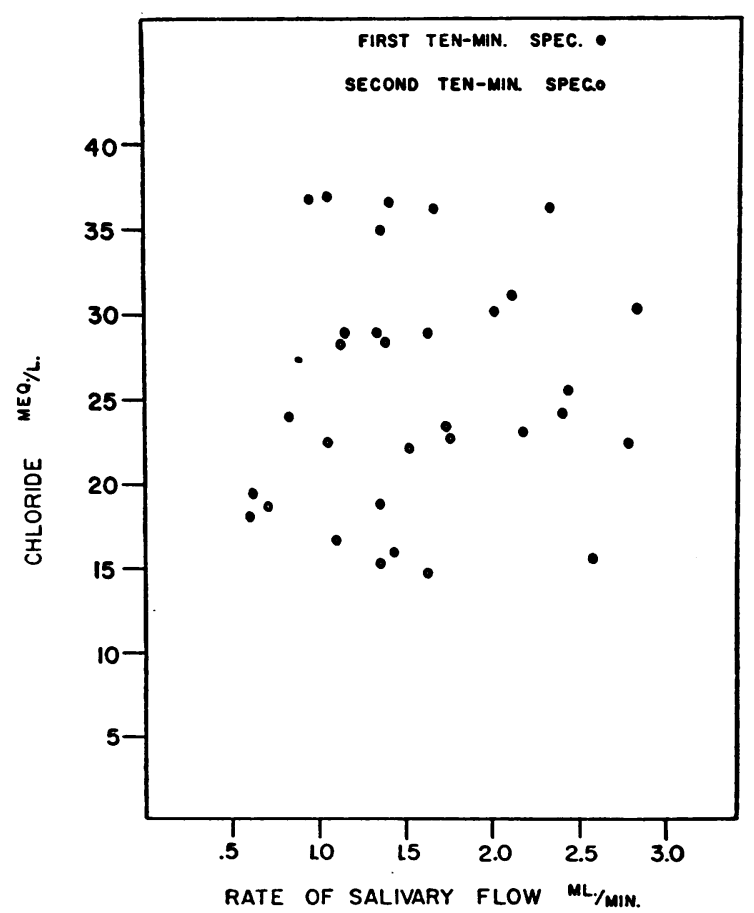

Fig. 2. Relation of the Salivary Concentration of Chloride (MEQ. Per L.) to Rate of Salivary Flow (ML. PER MIN.)
Effect of rate of flow on the concentrations of salivary electrolytes

There does not appear to be any highly significant effect of the rate of flow on these values (Figures $1,2,3)$. For the first 10-minute specimens, the regression lines, together with the corresponding correlation coefficients $(r)$ are :

$$
\begin{aligned}
& \mathrm{Na}: \mathrm{Y}_{\mathrm{c}}=14.83+5.98 \times(\mathrm{r}=.433) \\
& \mathrm{Cl}: \mathrm{Y}_{\mathrm{c}}=27.1+1.22 \times(\mathrm{r}=.283) \\
& \mathrm{K}: \quad \mathrm{Y}_{\mathrm{c}}=21.2-0.8 \times(\mathrm{r}=.283)
\end{aligned}
$$

The regression lines for the second 10-minute specimens are:

$$
\begin{array}{ll}
\mathrm{Na}: & \mathrm{Y}_{\mathrm{c}}=9.3+6.15 \times(\mathrm{r}=.5) \\
\mathrm{Cl}: & \mathrm{Y}_{\mathrm{c}}=22.7-0.45 \times(\mathrm{r}=.265) \\
\mathrm{K}: & \mathrm{Y}_{\mathrm{c}}=24.5-2.68 \times(\mathrm{r}=.51)
\end{array}
$$

Combined values for control subjects and for patients with congestive heart failure

The salivary concentrations of sodium, chloride, and potassium in the present series of patients with congestive heart failure are essentially the same as those for our earlier cardiac series. There is a statistically significant difference in the salivary electrolyte concentrations between the combined control group and the combined series of patients with congestive heart failure; for the

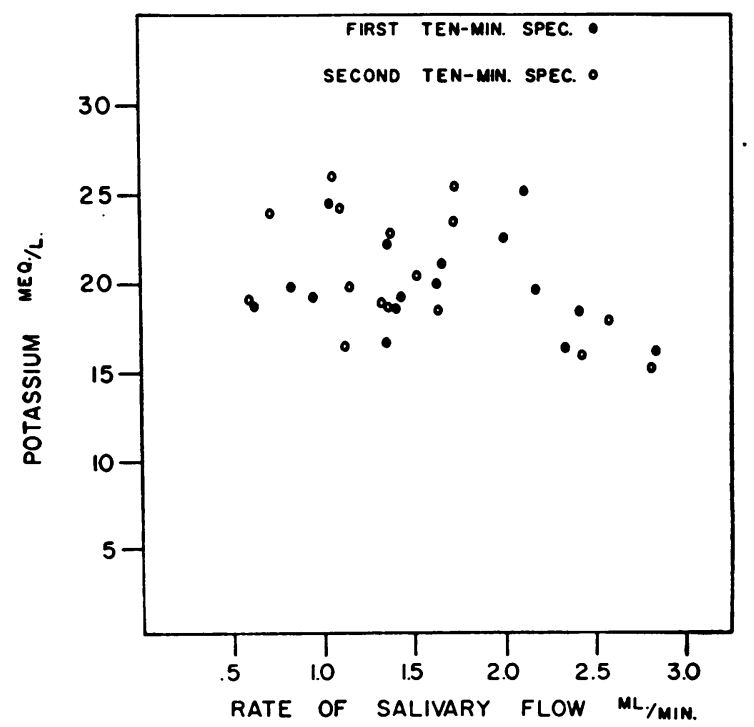

Fig. 3. Relation of the Salivary Concentration of Potassium (mEQ. per L.) to Rate of Salivary FLOW (ML. PER MIN.) 
cardiac patients on a regular diet containing up to 10 grams of salt per day does not increase their salivary sodium and chloride concentrations (1).

\section{Effect of desoxycorticosterone acetate on the con-} centrations of salivary electrolytes

As a result of the daily intramuscular injection of $10 \mathrm{mgm}$. DCA in oil for periods ranging from 5 to 15 days, the mean salivary electrolyte concentrations changed as follows: sodium decreased $3.8 \mathrm{mEq}$. per L., chloride decreased $5.9 \mathrm{mEq}$. per L. while potassium increased $1.8 \mathrm{mEq}$. per $\mathrm{L}$. (Table I, Figure 4). With the use of paired differences, statistical analysis showed that the changes in the concentrations of chloride and potassium were significant $(\mathrm{P}=.0002$ and .0008 , respectively), while that of sodium was not $(\mathrm{P}=$ $.14)$.

Statistical analysis (employing paired differences) yielded a "P" value of 0.09 for the decrease of 0.25 observed in the $\mathrm{Na} / \mathrm{K}$ ratio in eighteen subjects following the intramuscular administration of desoxycorticosterone acetate. No measurements were made of the effects of DCA on the rates of flow, but no gross changes were evident.

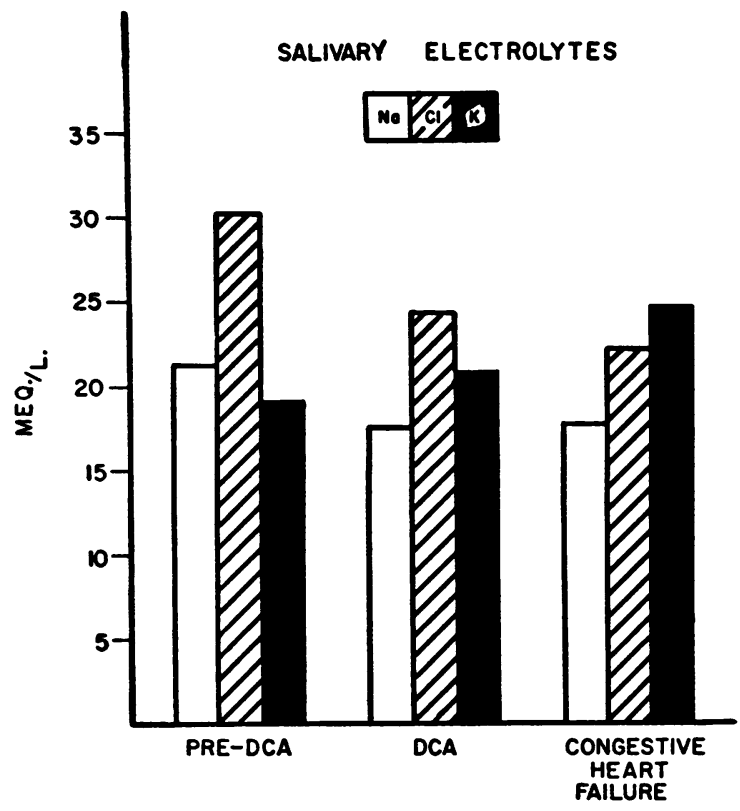

Fig. 4. EFfect OF INTRAMUSCULARLy-Administered Desoxycorticosterone Acetate (DCA) on Salivary Concentrations of Sodium, Chloride, and Potassium (MEQ. PER L.)

The corresponding concentrations in patients with congestive heart failure are shown for comparison.

TABLE III

The effect of intramuscularly administered Mercuhydrin (8) $(2 \mathrm{ml}$.) on the concentration of salivary electrolytes (paired differences)

\begin{tabular}{|c|c|c|c|c|c|c|c|c|c|c|c|c|}
\hline \multirow{2}{*}{ Subjects-C.H.F. } & \multicolumn{4}{|c|}{$\begin{array}{l}\text { Sodium } \\
m E q . / L \text {. }\end{array}$} & \multicolumn{4}{|c|}{$\begin{array}{l}\text { Chloride } \\
m E q . / L \text {. }\end{array}$} & \multicolumn{4}{|c|}{$\begin{array}{l}\text { Potassium } \\
m E q . / L .\end{array}$} \\
\hline & $\mathbf{n}$ & d & S.D. & S.E. & $\mathbf{n}$ & d & S.D. & S.E. & $\mathbf{n}$ & d & S.D. & S.E. \\
\hline \multirow{2}{*}{ 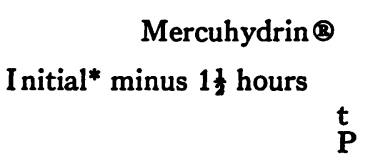 } & 10 & +.01 & 6.55 & 2.07 & 10 & -2.65 & 4.29 & 1.35 & 10 & -1.4 & 2.24 & .71 \\
\hline & \multicolumn{4}{|c|}{1.005} & \multicolumn{4}{|c|}{$\begin{array}{r}1.96 \\
.08\end{array}$} & \multicolumn{4}{|c|}{$\begin{array}{l}1.97 \\
.095\end{array}$} \\
\hline \multirow[t]{2}{*}{ I nitial minus 3 hours } & 10 & -.87 & 6.26 & 1.98 & 10 & -1.63 & 5.46 & 1.73 & 10 & -1.39 & 6.02 & 1.9 \\
\hline & \multicolumn{4}{|c|}{$\begin{array}{l}.44 \\
.68\end{array}$} & \multicolumn{4}{|c|}{$\begin{array}{l}.94 \\
.35\end{array}$} & \multicolumn{4}{|c|}{$\begin{array}{l}.73 \\
.48\end{array}$} \\
\hline \multirow[t]{2}{*}{ I nitial minus 24 hours } & 10 & +2.98 & 4.31 & 1.36 & 10 & +2.27 & 5.97 & 1.91 & 10 & +.27 & 3.1 & .98 \\
\hline & \multicolumn{4}{|c|}{$\begin{array}{l}2.19 \\
.056\end{array}$} & \multicolumn{4}{|c|}{$\begin{array}{r}1.19 \\
.26\end{array}$} & \multicolumn{4}{|c|}{$\begin{array}{l}.28 \\
.78\end{array}$} \\
\hline
\end{tabular}

* Av. initial values (mEq./L.):

$\mathrm{Na}, 15.4 \pm 8.2$

$\mathrm{Cl}, 22.5 \pm 7.7$

$\mathrm{K}, 23.8 \pm 5.2$ 


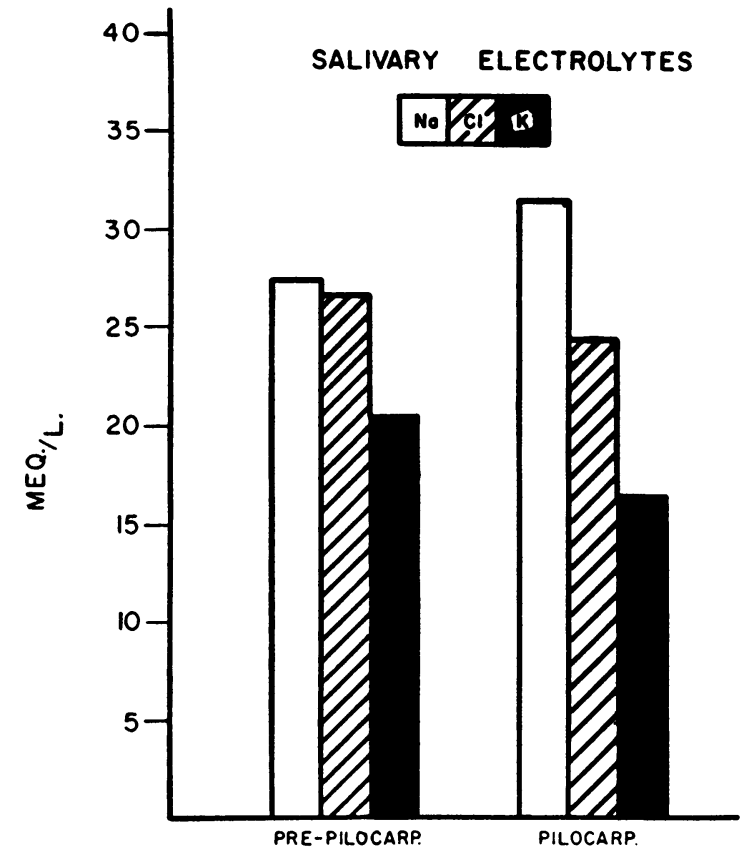

Fig. 5. The Effect of Subcutaneously-Administered Pilocarpine on the Salivary Concentrations of Sodium, Chloride, and Potassium

\section{Effect of pilocarpine on concentrations of salivary electrolytes}

Pilocarpine (6 mgm. administered subcutaneously) lowered the salivary concentration of potassium $3.97 \mathrm{mEq}$. per $\mathrm{L}$. $(\mathrm{P}=0.0001)$, lowered the chloride $2.42 \mathrm{mEq}$. per $\mathrm{L}$. $(\mathrm{P}=.065)$, and increased the sodium $4.11 \mathrm{mEq}$. per $\mathrm{L} .(\mathrm{P}=.069)$ (Table II, Figure 5). No measurements were

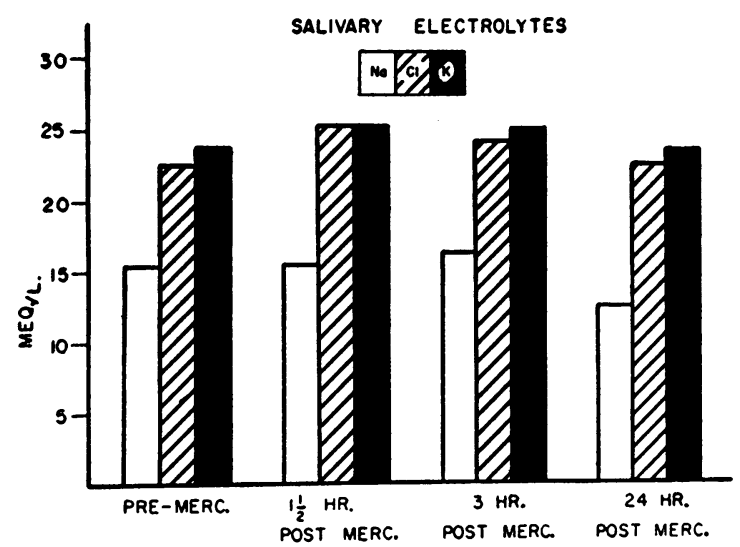

Fig. 6. The EFfect of Intramuscularly-Administered Mercuhydrin on the Salivary Concentratrons of Sodium, Chloride, and Potassium made of the rates of flow in this group of experiments.

\section{Effect of Mercuhydrin on concentrations of sali- vary electrolytes}

Mercuhydrin ${ }^{\circledR}$ (2 ml. injected intramuscularly) had no statistically significant effect on the salivary concentrations of sodium, chloride, or potassium, $1 \frac{1}{2}, 3$, and 24 hours following the injection of the diuretic (Table III, Figure 6). No measurements were made of the rates of flow.

\section{DISCUSSION}

Normal concentrations of salivary electrolytes

A. Methods of collecting saliva. Babkin (4) has summarized the basic physiological mechanisms underlying salivary secretion. Several important facts emerge regarding variations in the concentrations of electrolytes in human, mixed saliva. The nature of salivary secretion depends upon the type and duration of stimulus, and there also may be differences in the composition of saliva obtained from the parotid gland, on the one hand, and the mixed glands, on the other. Furthermore, it seems probable that there is no such thing as un-stimulated saliva in the human, because as soon as the subject opens his mouth, the oral cavity (and salivary glands) may receive secretory stimuli such as air currents. Therefore, the flow and composition of whole, mixed, human saliva represent a net result of multiple factors. It follows that almost any method of collecting human saliva must be somewhat arbitrary, but may suffice if : a) It yields a reproducible salivary composition; and b) variations in composition following an experimental stimulus or pharmacologic agent are not inhibited by the nature of the collecting method. The methods presented appear to satisfy these two requirements.

B. Effect of rate of salivary flow on the concentrations of electrolytes. Although the data presented are somewhat limited, they appear to indicate that under these experimental conditions, variations in the rate of human, mixed, salivary flow do not have any statistically, highly significant effects on the concentrations of sodium, chloride, or potassium (highest " $r$ " value calculated equals 0.51 ). Obviously, if the concentrations do 
not vary significantly with the rate of flow, there will tend to be a linear relationship between the rate of excretion of an electrolyte ( $\mathrm{mEq}$. per min.) and the rate of flow ( $\mathrm{ml}$. per min.).

In contrast to these results, Brown and Klotz (5) found that following the chewing of paraffin for one hour by eighteen subjects, the salivary concentrations of chloride and sodium varied directly with the rate of flow, while that of potassium tended to decrease slightly with increase in the rate of secretion. The much longer duration of stimulus to salivary secretion and the higher rates of salivary flow in their experiments may account for the discrepancy in the findings.

Studying the secretion of saliva by the dog's submaxillary gland following stimulation of the chorda tympani or the administration of pilocarpine, Gregersen and Ingalls (6) found that the concentration of sodium varied between 10 and $90 \mathrm{mEq}$. per L., depending closely on the rate of secretion. The concentration of potassium, on the other hand, remained approximately constant at 10 to $20 \mathrm{mEq}$. per L., depending on the type of stimulus (compare with the average of $19.7 \pm$ $3.9 \mathrm{mEq}$. per L. for 73 human subjects in the present series). Not only must the species difference be considered in comparing our findings with those of Gregersen and Ingalls, but their collection of saliva from one gland, the submaxillary, while in the present studies mixed saliva was collected (at a slower rate of flow) from all of the salivary glands. Furthermore, the stimulus was different, and Baxter ( 7 ) has reported that the concentrations of chloride, calcium, and potassium were much lower in the parotid saliva of dogs following the administration of pilocarpine than in the parotid saliva secreted at the same rate following the feeding of meat extract or bread and meat powder. It is apparent that the effect of the rate of salivary secretion on the concentrations of electrolytes is determined in part by the duration and type of stimulus.

\section{Effect of desoxycorticosterone acetate $(D C A)$ on the salivary concentrations of electrolytes}

Since these studies had their origin in earlier observations (1) suggesting adrenocortical control of salivary electrolyte concentrations, it is of interest that treatment with DCA resulted in statistically significant changes in the concentrations of chloride and potassium but not in that of sodium. Dissociation between changes in salivary sodium and chloride has been reported previously by McCance (8) who observed that acute salt deficiency in five normal subjects produced a consistent fall in the concentrations of salivary sodium while the corresponding changes in chloride were inconsistent.

The mean decrease of 0.25 in the $\mathrm{Na} / \mathrm{K}$ ratio following DCA is similar to the decrease observed by Frawley and Thorn (9) 24 hours after administering $15 \mathrm{mgm}$. DCA to each of two normal subjects, but appears to be of limited statistical significance.

While the salivary concentrations of sodium, chloride, and potassium following the administration of DCA approached those reported previously for normal subjects on a low-salt diet (1), the post-DCA values for salivary potassium did not rise to the relatively high levels observed in our patients with congestive heart failure. A possible explanation is that the imposition of a lowsalt regimen does not stimulate the elaboration of endogenous adrenocortical hormones in entirely the same way as the onset of congestive heart failure, so that a low-salt diet may stimulate the elaboration and secretion of greater amounts of a desoxycorticosterone-like fraction than does congestive heart failure.

Other work suggesting the adrenocortical regulation of salivary electrolytes includes the observations of Frawley and Thorn (9) on the increased salivary $\mathrm{Na} / \mathrm{K}$ ratio in patients with Addison's disease, with a decrease observed in Cushing's syndrome. These investigators also reported a fall of 18 to 68 per cent in the salivary $\mathrm{Na} / \mathrm{K}$ ratio following a standard 48-hour ACTH test administered to eight normal subjects, while under the same circumstances, four patients with Addison's disease showed no fall. Grad (10) has also reported a fall in the salivary $\mathrm{Na} / \mathrm{K}$ ratio following the administration of ACTH to four subjects, while Dreizen, Niedermeier, Reed, and Spies (11) reported decreases in salivary sodium following intramuscularly-administered ACTH or cortisone but no change in potassium. 
Effect of pilocarpine on the concentrations of salivary electrolytes

Previous studies on animals have demonstrated both increases and decreases in the salivary concentrations of sodium and chloride following the administration of pilocarpine, but all have been in agreement on the resulting decrease in the concentration of potassium. Evidence that this decrease in potassium cannot be ascribed solely to changes in the rate of salivary flow is provided by the work of Gregersen and Ingalls (6). Employing either electrical stimulation of the chorda tympani or the administration of pilocarpine, they demonstrated that for comparable rates of submaxillary salivary flow the concentrations of potassium (following pilocarpine) is approximately one-half that observed after stimulation of the chorda tympani. Following the administration of pilocarpine the potassium content of the submaxillary gland is decreased, while it remains essentially unchanged after electrical stimulation of the chorda tympani (12-14); these observations strengthen the probability that pilocarpine has a specific metabolic effect upon the salivary glands.

\section{Effect of Mercuhydrin ${ }^{\circledast}$ on the salivary concen- trations of electrolytes}

The absence of any significant effect of Mercuhydrin ${ }^{8}$ on the salivary concentrations of sodium, chloride, and potassium tends to emphasize the localized renal action of mercurial diuretics with respect to effects on the excretion of sodium, chloride, and potassium. In the dog, the intravenous administration of biochloride of mercury had no effect on the concentrations of electrolytes in saliva flowing in response to electrical stimulation of the chorda tympani (15).

\section{Relation of concentrations of electrolytes in saliva and blood, with discussion of possible regulating physiological mechanisms}

The salivary concentrations of sodium and chloride are much lower than their corresponding concentrations in serum, while that of potassium is approximately four times the serum concentration of this ion. In support of this lack of correlation between serum and salivary concentrations of sodium chloride, Doneddu (16) observed that the intravenous injection of $20 \mathrm{ml}$. of 30 per cent sodium chloride into human subjects did not significantly affect the salivary concentration of this salt in any case. De Beer and Wilson (17) studied the concentrations of sodium, chloride and potassium in parotid saliva after pilocarpine in dogs under Amytal anesthesia. While the concentrations of chloride (87 to $104 \mathrm{mEq}$. per L.) and sodium (123 to $130 \mathrm{mEq}$. per L.) tended to approach those in the serum at high rates of flow, the concentration of potassium (10.3 to $12.3 \mathrm{mEq}$. per L.) was higher than that in serum.

The classic explanation for the lower concentrations of sodium and chloride in saliva than in plasma has postulated an impaired permeability of the salivary glandular cell membrane to these ions (4). Presumably, with increased secretory activity the permeability to movement of sodium and chloride from the cell into the lumen increases, resulting in higher salivary sodium and chloride concentrations.

Possible reabsorptive function of rodded epithelium in excretory ducts. Another possibility, which seems more likely to us, is that sodium and chloride are secreted into the salivary duct lumen in isotonic concentrations and then undergo partial reabsorption in the duct cells. A possible basis for the reabsorption of chloride and/or sodium is provided by a study of the lining cells of the excretory ducts of five exocrine glands (the three salivary glands, the lacrimal gland, and the pancreas) Table IV. In 1883, Merkel (18) described the distribution of the rodded epithelial cells (Streifenzellen) in the excretory-duct systems of the salivary glands, pointing out that while the sublingual salivary gland has no such cells, the submaxillary has the longest tract of these cells and the parotid, a fairly well-developed duct system lined by rodded epithelium. In addition, the lacrimal glands and the pancreas, like the sublingual salivary gland, have no rodded epithelium in their excretory ducts. He postulated that the function of these cells is one of secretion of water and salts, especially calcium. However, the observed ash content of the secretions of the three glands does not agree with the amounts to be expected on the basis of Merkel's hypothesis; for example, the sublingual saliva has the highest ash content instead of the lowest, as would be 
TABLE IV

The relation between the presence of "rodded epithelium" in the ducts of exocrine glands and electrolyte concentrations of their corresponding secretions

\begin{tabular}{|c|c|c|c|c|c|}
\hline \multirow[b]{2}{*}{ Gland } & \multirow{2}{*}{$\begin{array}{l}\text { "Rodded } \\
\text { epithelium" } \\
\text { in duct } \\
(4)^{*}\end{array}$} & \multicolumn{4}{|c|}{ Secretion } \\
\hline & & $\begin{array}{c}\text { Relative } \\
\text { ash } \\
\text { content } \\
\text { (19) }\end{array}$ & $\begin{array}{c}\text { Absolute } \\
\text { ash } \\
\text { content } \\
(20)\end{array}$ & $\underset{m E q . / L}{C l}$ & $\underset{m E q . / L}{\mathrm{Na}}$ \\
\hline $\begin{array}{l}\text { Salivary } \\
\text { Sublingual }\end{array}$ & $\begin{array}{l}\text { Practically } \\
\text { absent }\end{array}$ & 2.0 & & $\begin{array}{c}121-185(19) \\
143\end{array}$ & \\
\hline Parotid & Well developed & 1.0 & $0.77 \%$ & $13.3-40.9$ (19) & \\
\hline Submaxillary & Longest & 0.7 & $0.53 \%$ & $\begin{array}{l}25.6-57.3(19) \\
51.3\end{array}$ & \\
\hline Lacrimal & Absent & & & $154(21)$ & $154(21)$ \\
\hline Pancreas & Absent & & & & $150(22)$ \\
\hline Mammary & Not known & & & $9-34(25)$ & $5-26(25)$ \\
\hline Sweat & Not known & & & $15-60(26)$ & $15-60(26)$ \\
\hline
\end{tabular}

* Reference numbers within parentheses.

in keeping with the absence of secretory, rodded epithelium.

Further evidence against the secretory nature (with respect to electrolytes) of the rodded epithelial cells was provided in 1886 by Werther (19) who employed pilocarpine stimulation, and confirmed much later by Baxter (20), who used stimulation of the chorda tympani. Both of these authors measured the chloride concentrations of saliva obtained separately from each of the three salivary glands. The sublingual saliva has the highest concentration of chloride-even higher than that of plasma-while the parotid and submaxillary glands yielded saliva with chlorides ranging from 13.3 to $57.3 \mathrm{mEq}$. per L. (Table IV).

The sodium and chloride content of tears is 154 mEq. per L. (21); while the sodium content of the pancreatic secretion is $150 \mathrm{mEq}$. per L. (22) ; and as mentioned previously, since no rodded epithelial cells occur in these glands, the concentrations of these ions should be low or nil if these cells indeed secreted electrolytes.

With iron hematoxylin stain rodded epithelial cells can be demonstrated in both the proximal and distal convoluted tubules $(23,24)$ of the kidney-acknowledged sites of sodium and chloride reabsorption. The concentrations of sodium and chloride in both milk (25), and sweat (26) are hypotonic, and we should expect, therefore, to find cells similar to the rodded epithelial cells in the excretory ducts of these glands. Unfortunately, a review of the available literature has not revealed any detailed histological investigations with the fixing and stains necessary to demonstrate the rodded epithelial cells.

In summary, it is apparent that the concentrations of chloride and/or sodium are isotonic with the plasma or even somewhat hypertonic in the secretions of those exocrine glands having no rodded epithelial cells in their excretory ducts. On the other hand, the chloride and/or sodium concentrations are hypotonic to plasma in the secretions of those glands having rodded epithelial cells in their excretory duct systems. This suggests, to us, a reabsorptive function of these cells.

Secretion of potassium. The high salivary concentration of potassium probably signifies a process of active secretion of this ion by the gland. A process of concentration through duct cell reabsorption of water seems to be excluded by the fact, for example, that the salivary non-protein nitrogen is approximately the same as that of serum.

\section{SUMMARY AND CONCLUSIONS}

1. Under standardized conditions of collection, the mean salivary concentration of sodium, potassium, and chloride in 73 normal subjects in the 
fasting state after chewing paraffin for 15 to 20 minutes was found to be: $\mathrm{Na}, 26.4 \pm 11.8 ; \mathrm{Cl}$, $29.0 \pm 8.8 ; \mathrm{K}, 19.7 \pm 3.9 \mathrm{mEq}$. per L.

2. After daily injections of desoxycorticosterone acetate (DCA) in oil for 5 to 15 days into 19 subjects there was a decrease of $3.8 \mathrm{mEq}$. per $\mathrm{L}$. in sodium $(P=.14)$, a decrease of $5.9 \mathrm{mEq}$. per $\mathrm{L}$. in chloride $(P=.0002)$, and an increase in potassium of $1.81 \mathrm{mEq}$. per $\mathrm{L}$. $(\mathrm{P}=.0008)$. DCA resulted in a mean decrease of 0.25 in the salivary $\mathrm{Na} / \mathrm{K}$ ratios $(\mathrm{P}=.09)$.

3. Following treatment with DCA, the salivary sodium and chloride approached the concentrations of those ions in the saliva of patients with congestive heart failure $(\mathrm{Na}, 17.8 \pm 8.9 ; \mathrm{Cl}, 22.2 \pm$ $8.4 \mathrm{mEq}$. per L.), but the potassium did not reach the relatively high concentration observed in the cardiac patients (K, $24.7 \pm 4.8 \mathrm{mEq}$. per L.).

4. The salivary concentrations of sodium, chloride, and potassium following DCA treatment were essentially the same as those reported previously by us for normal subjects on a salt-free diet $(\mathrm{Na}, 17.6 \pm 10.2 ; \mathrm{Cl}, 21.6 \pm 6.3 ; \mathrm{K}, 22.0 \pm 5.8$ mEq. per L.).

5. Pilocarpine, $6 \mathrm{mgm}$. administered subcutaneously to 29 subjects, increased the salivary concentration of sodium by $4.11 \mathrm{mEq}$. per L. ( $\mathrm{P}=$ .065 ), and lowered the potassium by $3.97 \mathrm{mEq}$. per L. $(P=.0001)$. Possible mechanisms of action of pilocarpine on the salivary glands are discussed.

6. Two ml. of Mercuhydrin ${ }^{\circledR}$, administered intramuscularly to 10 patients with congestive heart failure, had no statistically significant effect on the salivary concentrations of sodium, chloride, or potassium, $1 \frac{1}{2}, 3$, and 24 hours following the injection of the diuretic.

7. Limited studies, employing the chewing of paraffin as a stimulus, on the effect of the rate of salivary flow on the concentrations of sodium, chloride, and potassium showed some apparent increase in sodium and decrease in potassium as the rate of flow increased. However, these relationships were not as marked as in previous animal experiments reported in which relatively high rates of salivary flow were obtained and other types of stimulation employed.

8. It is suggested that salivary sodium and/or chloride concentrations are hypotonic to their respective serum concentrations as a result of reab- sorption of these ions by rodded epithelium in the excretory ducts. A concentration of potassium in saliva higher than that in serum is believed to represent active secretion of this ion by the gland. The concentrations of salivary electrolytes are compared with those in other exocrine secretions in respect to possible regulating mechanisms.

\section{REFERENCES}

1. White, A. G., Gordon, H., and Leiter, L., Studies in edema. II. The effect of congestive heart failure on saliva electrolyte concentrations. J. Clin. Invest., 1950, 29, 1445.

2. Van Slyke, D. D., and Hiller, A., Application of Sendroy's iodometric chloride titration to protein-containing fluids. J. Biol. Chem., 1947, 167, 107.

3. Snedecor, G. W., Statistical Methods Applied to Experiments in Agriculture and Biology, ed. 4, Ames, The Iowa State Collegiate Press, 1946.

4. Babkin, B. P., Secretory Mechanism of the Digestive Glands, ed. 2, New York, Paul B. Hoeber, Inc., 1950.

5. Brown, J. B., and Klotz, N. J., Studies on the chemistry of mixed human saliva. I. Attempts to correlate chemical composition of mixed human saliva with rate of secretion. J. Dent. Research, 1934, 14, 435. II. Sodium, potassium and calcium in salivas secreted at widely varying rates. J. Dent. Research, 1937, 16, 19.

6. Gregersen, M. I., and Ingalls, E. N., The influence of rate of secretion on the concentration of potassium and sodium in dog's submaxillary saliva. Am. J. Physiol., 1931, 98, 441.

7. Baxter, $H$., Variations in the inorganic constituents of mixed and parotid gland saliva activated by reflex stimulation in the dog. J. Biol. Chem., 1933, 102, 203.

8. McCance, R. A., The effect of salt deficiency in man on the volume of the extracellular fluids, and on the composition of sweat, saliva, gastric juice and cerebrospinal fluid. J. Physiol., 1938, 92, 208.

9. Frawley, T. F., and Thorn, G. W., The relation of the salivary sodium-potassium ratio to adrenal cortical activity. Proc. 2nd Clin. ACTH Conf., Philadelphia, The Blakiston Co., 1951, 1, 115.

10. Grad, B., The influence of ACTH on the sodium and potassium concentration of human mixed saliva. J. Clin. Endocrinol. \& Metab., 1952, 12, 708.

11. Dreizen, S., Niedermeier, W., Reed, A. I., and Spies, T. D., The effect of ACTH and cortisone on the sodium and potassium levels of human saliva. $\mathrm{J}$. Dent. Research, 1952, 31, 271.

12. Wills, J. H., and Fenn, W O., Potassium changes in submaxillary glands during stimulation. Am. J. Physiol., 1938, 124, 72. 
13. Wills, J. H., Electrolyte changes in submaxillary glands during stimulation. Am. J. Physiol., 1941, 135, 164.

14. Cicardo, V. H., and Torino, A., Liberation of potassium by the submaxillary glands during their activity, (Desprendimiento de potasio por las glándulas submaxilares durante su actividad). Rev. Soc. argent. de biol., 1943, 19, 66-70.

15. Melville, K. I., Concerning mechanism of mercurial salivation. Arch. internat. de pharmacodyn. et de thérap., 1930, 37, 143.

16. Doneddu, C. di, La eliminazione salivare di cloruro di sodio, a digiuno e dopo carico salino endovenoso, nei normale e nei gastropazienti. Boll. Soc. ital. biol. sper., 1943, 18, 190.

17. De Beer, E. J., and Wilson, D. W., The inorganic composition of the parotid saliva of the dog and its relation to the composition of the serum. J. Biol. Chem., 1932, 95, 671.

18. Merkel, F., Die Speichelröhren. Rectoratsprogramm. Leipzig, F. C. W. Vogel, 1883. Quoted by Babkin (4).

19. Werther, M., Einige Beobachtungen über die Absonderung der Salze im Speichel. Pflüger's Arch. f. d. ges. Physiol., 1886, 38, 293. Quoted by Babkin (4).
20. Baxter, H., Unpublished data. Quoted by Babkin (4).

21. Adler, F. H., Physiology of the Eye, Clinical Application. St. Louis, C. V. Mosby Co., 1950.

22. McCance, R. A., Medical problems in mineral metabolism. Lancet, 1936, 1, 704.

23. Oliver, J. R., and Lund, E. M., Cellular mechanisms of renal secretion; a study by the extravital method. I. The structural phase of the secretory mechanism. J. Exper. Med., 1933, 57, 435; II. The functional phase of the secretory mechanism, ibid., 1933, 57, 459.

24. v. Möllendorff, W., Der exkretionsapparat in v. Möllendorff, W., Handbuch der mikroskopischen anatomie des menschen, Berlin, Julius Springer, 1927, vol. 7, pp. 1-328.

25. Hawk, P. B., Oser, B. L., and Summerson, W. H., Practical Physiological Chemistry, ed. 12, Philadelphia, Blakiston Co., 1947; also unpublished data in this laboratory.

26. Conn, J. W., Electrolyte composition of sweat, clinical implications as an index of adrenal cortical function. Arch. Int. Med., 1949, 83, 416. 